\title{
Production of functional inclusion bodies in endotoxin-free Escherichia coli
}

Fabián Rueda ${ }^{1,2,3}$, Olivia Cano-Garrido ${ }^{1,2,3}$, Uwe Mamat ${ }^{4}$, Kathleen Wilke ${ }^{4}$, Joaquín Seras-Franzoso ${ }^{1,2,3}$, Elena García-Fruitós ${ }^{3,1,2^{*}}$, Antonio Villaverde ${ }^{1,2,3^{*}}$

1 Institut de Biotecnologia i de Biomedicina, Universitat Autònoma de Barcelona, Bellaterra, 08193 Cerdanyola del Vallès, Spain.

2 Departament de Genètica i de Microbiologia, Universitat Autònoma de Barcelona, Bellaterra, 08193 Cerdanyola del Vallès, Spain.

${ }^{3}$ CIBER de Bioingeniería, Biomateriales y Nanomedicina (CIBER-BBN), Bellaterra, 08193 Cerdanyola del Vallès, Spain.

${ }^{4}$ Division of Structural Biochemistry, Research Center Borstel, Leibniz-Center for Medicine and Biosciences, D-23845 Borstel, Germany.

"corresponding authors.
A. Villaverde
e-mail, antoni.villaverde@uab.es
phone, +34935813084
fax, +34935812011

Keywords : E. coli; recombinant protein; inclusion bodies; endotoxin; LPS; LPS-free 


\section{Abstract}

Escherichia coli is the workhorse for gene cloning and production of soluble recombinant proteins in both biotechnological and biomedical industries. The bacterium is also a good producer of several classes of protein-based self-assembling materials such as inclusion bodies (IBs). Apart from being a relatively pure source of protein for in vitro refolding, IBs are under exploration as functional, protein-releasing materials in regenerative medicine and protein replacement therapies. Endotoxin removal is a critical step for downstream applications of therapeutic proteins. The same holds true for IBs as they are often highly contaminated with cell-wall components of the host cells. Here we have investigated the production of IBs in a recently developed endotoxin-free $E$. coli strain. The characterization of IBs revealed this mutant as a very useful cell factory for the production of functional endotoxin-free IBs that are suitable for the use at biological interfaces without inducing endotoxic responses in human immune cells. 


\section{Introduction}

Recombinant proteins produced in the Gram-negative bacterium Escherichia coli tend to be deposited as insoluble protein clusters known as inclusion bodies (IBs). These protein particles, ranging from 50 to around $500 \mathrm{~nm}$ in diameter, are emerging protein materials with intriguing biomedical applications (Garcia-Fruitos et al. 2011; Villaverde et al. 2012; Villaverde 2012), that can be regarded as biomimetics of functional amyloids (protein repositories for sustained release) acting in the endocrine system (Maji et al. 2009; Badtke et al. 2009; Mankar et al. 2011; Cano-Garrido et al. 2013). Bacterial IBs show high biological activity (Garcia-Fruitos et al. 2005; GonzalezMontalban et al. 2007; Garcia-Fruitos et al. 2012), spontaneous penetrability in mammalian cells (Vazquez et al. 2012) and also mechanical and biological stability (Diez-Gil et al. 2010; García-Fruitós et al. 2009), which has allowed to adapt them as nanostructured materials for surface decoration in tissue engineering (García-Fruitós et al. 2009; Seras-Franzoso et al. 2013b; Tatkiewicz et al. 2013; Diez-Gil et al. 2010; Seras-Franzoso et al. 2011; Seras-Franzoso et al. 2012; Seras-Franzoso J et al. 2013) and in the context of top-down and bottom-up protein replacement/delivery cell therapies (Vazquez et al. 2012; Cano-Garrido et al. 2013; Talafova et al. 2013; Liovic et al. 2012). However, these applications require the bacterial product being free of $E$. coli-derived lipopolysaccharide (LPS) that is capable of inducing an endotoxic immune response in humans and other mammals. If present, these bacterial contaminants can severely restrict the biomedical applicability of the material. So far, the efforts addressed to obtain pure IBs have been focussed on the development of optimized cell-disruption methods for the isolation of these sub-micron particles lacking bacterial cells (Rodriguez-Carmona et al. 2010). However, the preparation of cell-free IBs, while preventing further bacterial contamination, does not guarantee the absence of free or IB-associated LPS. In fact, cell-wall contaminants are believed to associate with IBs during the disruption and separation processes (Georgiou and Valax 1999). In the present study, we have therefore addressed the question of functional IB production in a recently developed endotoxin-free $E$. coli strain, in order to overcome limitations caused by the potential presence of endotoxin in IB preparations. 


\section{Material and methods}

Strains, media and plasmids

The E. coli K-12 strains used in this study were MC4100 ([araD139], (argF-lac)169, $\lambda$ relA1, rpsL150, rbsR22, flb5301, deoC1, pstF25 Strep ${ }^{\mathrm{R}}$ ), BW30270 (CGSC\#7925 MG1655; $\left.\mathrm{F}^{-}, r p h^{+}, f n r^{+}\right)$and its isogenic endotoxin-free strain KPM335 ( $m s b A 52, \Delta$ gutQ, $\Delta k d s D, \Delta / p x L, \Delta / p x M, \Delta p a g P, \Delta / p x P, \Delta e p t A$, frr181). KPM335 will be described in detail elsewhere. All these strains were transformed with $\mathrm{pTr}$ T9a-VP1GFP $\left(A p^{R}\right)$ encoding the fusion protein VP1GFP, an aggregation-prone fluorescent protein previously used as a reporter to study IB formation (Garcia-Fruitos et al. 2007). Both transformed and plasmid-free E. coli strains were cultured in Luria-Bertani (LB Miller) media (J.Sambrook et al. 1989).

\section{Competent cells}

Overnight cultures of MC4100 and BW32070 grown at $37^{\circ} \mathrm{C}$ and 250 rpm were used as a $1 / 100$ inoculum in $50 \mathrm{ml}$ of LB. When the cells reached the early exponential growth phase at an optical density $\left(\mathrm{OD}_{550}\right)$ between $0.2-0.4$ at $37^{\circ} \mathrm{C}, 25-\mathrm{ml}$ aliquots of the cultures were centrifuged $(4,000 \times g)$ at $4^{\circ} \mathrm{C}$ for $15 \mathrm{~min}$. Pellets were resuspended in $12.5 \mathrm{ml}$ of cold and sterile $50 \mathrm{mM} \mathrm{CaCl}_{2}$ and left for $45 \mathrm{~min}$ in an ice bath. Cells were centrifuged again under the same conditions as described above and resuspended in $1.25 \mathrm{ml}$ of cold and sterile $50 \mathrm{mM} \mathrm{CaCl}_{2}$. Finally, aliquots of $200 \mu \mathrm{l}$ in $\mathrm{CaCl}_{2} /$ glycerol $(15 \% \mathrm{v} / \mathrm{v})$ were stored at $-80^{\circ} \mathrm{C}$.

\section{Electrocompetent cells}

KMP335 cells were grown overnight at $37^{\circ} \mathrm{C}$ and $250 \mathrm{rpm}$ and diluted $1 / 50$ in $80 \mathrm{ml}$ of LB. The cells were grown to an $\mathrm{OD}_{550}$ between $0.2-0.4$, placed on ice for $20 \mathrm{~min}$ and sedimented by centrifugation ( $3100 \times g, 4 \stackrel{\circ}{ } \mathrm{C}, 20 \mathrm{~min})$. The bacterial cells were washed successively in 40, 20 and $10 \mathrm{ml}$ of $\mathrm{H}_{2} \mathrm{O}$ (ice-cold and sterile), followed by an additional washing step in $5 \mathrm{ml}$ of $10 \%$ glycerol (ice-cold and sterile), resuspension of the final cell sediment in $1 \mathrm{ml}$ of $10 \%$ glycerol (ice-cold and sterile), and preparation of $50-\mu l$ aliquots for electroporation. 


\section{Transformation}

Transformation of competent MC4100 and BW32070 cells was performed using $40 \mathrm{ng}$ of plasmid DNA. The transformation mixtures were incubated on ice for $30-60 \mathrm{~min}$ and then warmed up to $42^{\circ} \mathrm{C}$ for $45 \mathrm{sec}$. The mixtures were then immediately placed on ice for $30 \mathrm{sec}$, and $800 \mu \mathrm{l}$ of LB were added, followed by incubation of the transformed cells at $37^{\circ} \mathrm{C}$ for $1 \mathrm{~h}$. Cells were plated on LB-agar plates containing ampicillin (100 $\mu \mathrm{g} / \mathrm{ml}$ ) and incubated overnight at $37^{\circ} \mathrm{C}$. KPM335 cells were transformed by electroporation in a pre-chilled $0.2-\mathrm{cm}$ gap electroporation cuvette using $50 \mu \mathrm{l}$ of competent cells and $40 \mathrm{ng}$ of plasmid DNA. Cells were pulsed using a Gene Pulser MX cell electroporator (Bio-Rad, Hercules, CA, USA) at $25 \mu \mathrm{F}, 200 \Omega, 2,500 \mathrm{~V}$ and 4.7 $4.8 \mathrm{msec}$. Immediately after the pulse, $800 \mu \mathrm{l}$ of LB medium were added, and the mixture was incubated at $37^{\circ} \mathrm{C}$ for $1 \mathrm{~h}$. The culture was plated on LB-agar plates containing ampicillin $(100 \mu \mathrm{g} / \mathrm{ml})$ and incubated at $37^{\circ} \mathrm{C}$ overnight.

\section{Protein production}

VP1GFP was produced at three growth temperatures $\left(37^{\circ} \mathrm{C}, 2^{\circ} \mathrm{C}\right.$ and $\left.16^{\circ} \mathrm{C}\right)$. Overnight cultures were inoculated each in triplicate in three 250-ml shake flasks containing $50 \mathrm{ml}$ of LB media with $100 \mu \mathrm{g} / \mathrm{ml}$ ampicillin (plus $30 \mu \mathrm{g} / \mathrm{ml}$ streptomycin in MC4100) and incubated at $37^{\circ} \mathrm{C}$ and $250 \mathrm{rpm}$ until the cells reached the midexponential growth phase between 0.5 and $0.6 \mathrm{OD}_{550}$ units. Recombinant gene expression was then induced by the addition of IPTG to a final concentration of $1 \mathrm{mM}$. Cultures were then incubated for either $3 \mathrm{~h}$ at $37^{\circ} \mathrm{C}$ or overnight at $25^{\circ} \mathrm{C}$ and $16^{\circ} \mathrm{C}$. At the indicated times, $20 \mathrm{ml}$ of each culture were harvested by centrifugation $(10,000 \times \mathrm{g}$, $\left.4^{\circ} \mathrm{C}, 10 \mathrm{~min}\right)$. The pellets were resuspended in $1 \mathrm{ml}$ PBS containing the Complete EDTA-free protease inhibitor cocktail (Roche Diagnostics, Indianapolis, USA). Cells were disrupted by 5 -min cycles and pulses of 0.5 seconds (power at $40 \%$ ) using a Lab Sonic ultrasonicator (B. Braun, Mesulgen, Germany). Each cell lysate was separated into two aliquots of $500 \mu \mathrm{l}$ for protein quantification by Western blot analysis and fluorescence measurement. Aliquots of the IB samples were centrifuged $(15,000 \mathrm{~g}$, $4^{\circ} \mathrm{C}, 15 \mathrm{~min}$ ), and both the IB pellets and the supernatants were stored at $-20^{\circ} \mathrm{C}$.

IB purification 
Overnight cultures of MC4100, BW32070 and KPM335 grown at $37^{\circ} \mathrm{C}$ and $250 \mathrm{rpm}$ were used as a 1/100 inoculum in 500-ml of LB and VP1GFP IBs were produced at 37 ${ }^{\circ}$ C. After production, Lysozyme $(1 \mu \mathrm{g} / \mathrm{ml})$, phenylmethylsulfonyl fluoride $(0.4 \mathrm{mM})$ and EDTA-free protease inhibitor cocktail (Complete EDTA-free Roche Diagnostics, Indianápolis, USA) were added and cultures were incubated for $2 \mathrm{~h}$ at $37^{\circ} \mathrm{C}$ and 250 $\mathrm{rpm}$. Mixtures were stored at $-80^{\circ} \mathrm{C}$. Cultures were thawed at room temperature, and 2 $\mathrm{ml}$ of Triton X-100 (Roche Diagnostics, Indianapolis, USA) were added and left at room temperature for $1 \mathrm{~h}$. As a bacterial viability control, $100 \mu \mathrm{l}$ of the culture were plated on LB-agar without antibiotics, and the samples were stored again at $-80^{\circ} \mathrm{C}$. Freeze-thaw cycles were repeated until no colony was found on the plates. Once the absence of viable bacteria was confirmed, $125 \mu$ l of nonyl phenoxypolyethoxylethanol (NP-40) (Roche Diagnostics, Indianapolis, USA) were added, followed by incubation of the samples at $4^{\circ} \mathrm{C}$ for $1 \mathrm{~h}$. After incubation, $\mathrm{MgSO}_{4} 0.6 \mathrm{M}$ and DNase $0.6 \mu \mathrm{g} / \mathrm{ml}$ were added (Roche Diagnostics, Indianapolis, USA). The samples were incubated at $37^{\circ} \mathrm{C}$ for $1 \mathrm{~h}$ with shaking and centrifuged $\left(15,000 \times g, 4^{\circ} \mathrm{C}, 15 \mathrm{~min}\right)$. The pellets were subsequently resuspended with $25 \mathrm{ml}$ of lysis buffer $(50 \mathrm{mM}$ Tris $\mathrm{HCl}, \mathrm{pH} 8.0,100 \mathrm{mM}$ $\mathrm{NaCl}, 1 \mathrm{mM}$ EDTA containing $0.5 \%$ Triton $\mathrm{X}-100)$ containing $0.5 \%$ Triton $\mathrm{X}-100$ (Roche Diagnostics, Indianapolis, USA). $100 \mu \mathrm{l}$ of each sample were plated on LB-agar without antibiotics, and the plates were incubated at $37^{\circ} \mathrm{C}$ overnight. The samples were centrifuged again under the same conditions as described above. The pellets were resuspended in PBS, and $100 \mu$-aliquots were plated to monitor bacterial viability. Finally, the resuspended pellets containing the IBs were separated into 5-ml aliquots and sedimented again by centrifugation $\left(15,000 \times g, 4^{\circ} \mathrm{C}, 15 \mathrm{~min}\right)$. The supernatants were discarded, and the pellets were stored at $-80^{\circ} \mathrm{C}$.

\section{SDS-PAGE and Western blot analysis}

Protein quantification was performed by sodium dodecylsulfate polyacrylamide gel electrophoresis (SDS-PAGE) using 10\% polyacrylamide gels according to Laemmli's method (Laemmli 1970). For quantification, the GFP-H6 protein at 500, 250, 125, 75 and $37.5 \mathrm{ng}$ (Vazquez et al. 2010) was used as a standard on each gel. Soluble protein samples were denatured by incubation at $98^{\circ} \mathrm{C}$ for 5 minutes, whereas IBs were incubated for $40 \mathrm{~min}$. For Western blot analyses, protein samples were electrotransferred to nitrocelulose membranes (GE Healthcare, Buckinghamshire, England) using $10 \%$ glycine, $20 \%$ methanol in $\mathrm{H}_{2} \mathrm{O}$ as a transfer buffer. The membranes were blocked with $5 \%$ milk powder in PBS overnight, followed by 
incubation of the membranes with anti-GFP antibody as recommended by the manufacturer (sc-8334, Santa Cruz Biotechnology, CA, USA). HRP-conjugated antirabbit lgG $(\mathrm{H}+\mathrm{L})$ antibody (Bio-Rad, Hercules, CA, USA) at a dilution of 1/2000 was used as a secondary antibody. The membranes were developed in a solution consisting of $25 \%$ cold methanol, $0.2 \% \mathrm{H}_{2} \mathrm{O}_{2}$ and $0.65 \mathrm{mg} / \mathrm{ml}$ of 4 -chloronaftol in PBS. Images of the membranes were obtained using a GS800 Calibrated Densitometer scanner (Bio-Rad, Hercules, CA, USA). The protein amount of the bands was analyzed from the standard curve fitting equation of GFP-H6 using the Quantity One software.

\section{Determination of GFP fluorescence}

To determine the fluorescence of GFP, IBs were resuspended in $1 \mathrm{ml}$ PBS, whereas supernatants $(0.5 \mathrm{ml}$ of soluble protein) were mixed with $0.5 \mathrm{ml}$ PBS. Measurements were performed in a fluorescence spectrometer Cary Eclipse (Varian, Mulgrave Australia) using $1-\mathrm{ml}$ cuvettes at $450 \mathrm{~nm}$ of excitation wavelength and $510 \mathrm{~nm}$ of emission wavelength.

\section{Statistical analysis}

The data were analyzed using a GLM model under a completely randomized design with a factorial array of $4 \times 3$ (4 strains $\times 3$ production temperatures) according to the following equation:

$Y_{i j}=\mu+\alpha_{i}+\beta_{j}+\left(\alpha_{i} \beta j\right)+E_{i j}$

Where:

$Y_{i j}=$ Protein quantity, fluorescence, specific fluorescence (soluble and IBs)

$\mu=$ Total mean of each variable

$\alpha_{\mathrm{i}}=$ Strain effect

$\beta_{\mathrm{j}}=$ Temperature effect

$\left(\alpha i \beta_{\mathrm{j}}\right)=$ Interaction strain-temperature effect

$E_{i j=}$ Experimental Error

Moreover, a least square comparison test of each production was made for all variables. 


\section{Light microscopy}

For visualization of bacterial cells and IBs, $1 \mathrm{ml}$ of each sample was centrifuged at $10,000 \times g$ and $4^{\circ} \mathrm{C}$ for $10 \mathrm{~min}$. Pellets were resuspended in $1 \mathrm{ml}$ of $0.1 \%$ formaldehyde in PBS. Images were examined at $100 \times$ magnification in the dark field with fluorescence and phase contrast using a Leica DRMB microscope (Leica Microsystems, Wetzlar, Germany). Images were digitalized using the Leica LAS 3.0 software.

\section{Scanning electron microscopy}

Purified IBs were resuspended in PBS-Tween-20 buffer and filtered using a $0.2 \mu \mathrm{m}$ Nucleopore Whatman membrane (GE Healthcare, Buckinghamshire, England). Membranes were fixed with $2.5 \%$ glutaraldehyde-phosphate at $4^{\circ} \mathrm{C}$ for $1 \mathrm{~h}$. After fixing, the samples were dehydrated through sequential washes with ethanol (Sharlau Microbiologics, Barcelona, Spain) at increasing concentrations from 50 to $99 \%$ during 15-30 min. Remaining Ethanol was evaporated in a K850 CDP desiccator (Emitech, Ashford, UK), and dry membranes were covered with gold using a Sputter Coater k550 (Emitech, Ashford, UK). Examination of the specimens was performed at accelerations between 0.5 and $30 \mathrm{kV}$ using a Hitachi s-570 scanning electron microscope (Hitachi Ltd, Tokio, Japan).

\section{Cell proliferation assay}

Human skin fibroblast cells (1BR3.G) were grown at $37^{\circ} \mathrm{C}$ and $10 \% \mathrm{CO}_{2}$ on IBdecorated surfaces. For that, $1 \mu \mathrm{g}$ of VP1GFP IBs were added to each well of an untreated Costar 3370 plate and incubated with Dulbecco's Modified Eagle's Medium (DMEM) at $4^{\circ} \mathrm{C}$ overnight. After incubation, the medium was replaced, and nonattached IBs were washed out three times using $200 \mathrm{ml}$ of filtered and sterile PBS. 1BR3.G cells were added (5,000 cells per well) in DMEM medium with $2 \%$ of Fetal Bovine Serum (FBS). Plates were incubated at $37^{\circ} \mathrm{C}$ for 24,48 and 72 hours, and the MTT proliferation cell assay was performed using the Nonradioactive Cell Proliferation and Cytotocity Assay Kit EZ4U as recommended by the manufacturer (Biomedica Medizinprodukte $\mathrm{GmbH}$, Wien, Austria). Absorbance was measured in a multilabel 
reader VICTOR3 V1420 (Perkin Elmer) at $450 \mathrm{~nm}$ (and $620 \mathrm{~nm}$ as reference), and the values were standardized with respect to the negative control.

IB internalization test

HeLa cells $(60,000$ cells per well) were seeded in treated 12 well plates (Nunclon surface, Nunc 150628) in the presence of MEM-a medium supplemented with $10 \%$ FBS and $2 \mathrm{mM}$ Glutamax (Gibco, Rockville MD) . After incubation at $37^{\circ} \mathrm{C}$ and $5 \% \mathrm{CO}_{2}$ for $24 \mathrm{~h}$, the medium was removed, and the cells were washed with DPBS. Then, $5 \mu \mathrm{g}$ of VP1GFP IBs were suspended in MEM- $\alpha$ containing 10\% FBS and 2 mM Glutamax, and added per well. After $48 \mathrm{~h}$, cell samples were treated with trypsin $(1 \mathrm{mg} / \mathrm{ml})$ in DPBS for $15 \mathrm{~min}$, and samples were analyzed on a FACSCanto system (Becton Dickinson) using a $15 \mathrm{~W}$ air-cooled argon-ion laser at $488 \mathrm{~nm}$ excitation for GFP. Fluorescence emission was measured with a 530/30 nm band pass filter

\section{LPS detection assay}

The LPS detection assay using tenfold serial dilution steps of VP1GFP IBs was performed with HEK-Blue ${ }^{\text {TM }}$ hTLR4 cells in accordance with the specifications of the

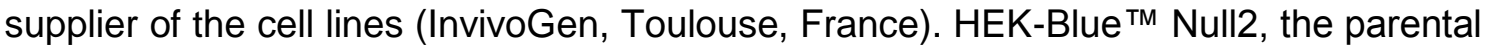
cell line of HEK-Blue ${ }^{\mathrm{TM}}$ hTLR4, was used as a control. 


\section{Results}

To investigate the formation of IBs by the aggregation-prone VP1GFP protein, wildtype and endotoxin-free $E$. coli strains carrying the pTr99a-VP1GFP plasmid were grown aerobically in LB medium containing $100 \mu \mathrm{g} / \mathrm{ml}$ ampicillin at $37^{\circ} \mathrm{C}, 25^{\circ} \mathrm{C}$ and $16^{\circ} \mathrm{C}$. As shown in Figure 1, the optical densities at $550 \mathrm{~nm}\left(\mathrm{OD}_{550}\right)$ of all cultures following induction of recombinant gene expression for three hours did not differ considerably from each other, although the endotoxin-free strain KPM335 consistently reached lower $\mathrm{OD}_{550}$ values than its parental wild-type strain BW30270 and the MC4100 control strain at all three temperatures.

Production and separation of VP1GFP into soluble and insoluble fractions revealed that the amounts of recombinant VP1GFP obtained from MC4100 and BW30270 were usually similar, but about twice the amount than in the endotoxin-free strain KPM335 at $37^{\circ} \mathrm{C}$ (Fig. 2). In KPM335, the total amount of soluble VP1GFP was higher than in wild type strains. Strikingly, no insoluble protein was detected in KPM335 at $16^{\circ} \mathrm{C}$. The intensity of GFP fluorescence of both the soluble and the insoluble fraction (Fig. 3A) was in accord with the protein amount obtained from the E. coli strains (Fig. 2). As expected, specific fluorescence of insoluble VP1GFP was in general lower than that of the soluble protein, with very low levels in MC4100 and BW30270 at $37^{\circ} \mathrm{C}$ (Fig. 3B). As a general trend, specific fluorescence of the soluble protein increased with lower culture temperatures, indicative of improved protein folding.

Interestingly, insoluble VP1GFP produced in KPM335 showed the highest specific fluorescence at each temperature when compared with the insoluble fraction from the wild-type strains (Fig. 3B), suggesting a higher conformational and, therefore, functional quality of IBs produced in the LPS-free strain. this fact could be of bionanotechnological relevance if in this strain, the insoluble protein is organized as inclusion bodies (IBs). IBs, as sub-micron protein particles, are gaining relevance in biotechnology (Garcia-Fruitos et al. 2012) and biomedicine (Vazquez and Villaverde 2013) because of their penetrability in mammalian cells in absence of toxicity and their ability to release therapeutic proteins inside receiving cells, in either substitutive protein therapies (Liovic et al. 2012; Talafova et al. 2013; Vazquez et al. 2012) or in tissue engineering (Seras-Franzoso J et al. 2013; Cano-Garrido et al. 2013; Seras-Franzoso et al. 2013b; Seras-Franzoso et al. 2013a). Interestingly, they act as natural biomimetics of hormone-releasing secretory granules of the endocrine system (Villaverde 2012), what offers a plethora of therapeutic opportunities. 
The formation of fluorescent IBs in KPM335 was confirmed by light microscopy (Fig. 4C). Like IBs produced in MC4100 and BW30270 (Figs. 4A and 4B) and commonly observed in IB-producing bacteria (Villaverde and Carrio 2003), the IBs in KPM335 appeared as refractile particles adopting a polar distribution. The fluorescent intensity was also highest here in KPM335 (Fig. 4C) and, thus, in good agreement with measurements using fluorometry (Fig. 3B). However, the pseudo-spherical morphology and size between 300 and $500 \mathrm{~nm}$ of the IBs formed in MC4100, BW30270 and KPM335 were indistinguishable from each other (Fig. 5) and similar to IBs isolated from other E. coli strains (Garcia-Fruitos et al. 2010).

The endotoxic activity of the IBs produced in E. coli strains MC4100, BW30270 and KPM335 was investigated using the HEK-Blue ${ }^{\text {TM }}$ hTLR4 LPS detection assay. As shown in Figure 6, the hTLR4 stimulating activity of IBs from KPM335 was of several orders of magnitude lower compared with the ability of IBs from the wild-type strains to stimulate the hTLR4 signaling pathway.

Apart from the highest specific fluorescent intensity and the extremely low endotoxic activity, IBs formed in KPM335 were indistinguishable from those obtained from its parental strain or the common MC4100 laboratory strain. However, we wanted to ensure that these particles still retained their ability to (i) mechanically stimulate the growth of mammalian cells when used as surface-decorating topographies in cell culture settings as described previously (García-Fruitós et al. 2009; Seras-Franzoso et al. 2013c; Diez-Gil et al. 2010; Tatkiewicz et al. 2013; Seras-Franzoso et al. 2013b), and (ii) release functional proteins when internalized by mammalian cells (Liovic et al. 2012; Vazquez et al. 2012; Seras-Franzoso J et al. 2013; Seras-Franzoso et al. 2013b). The comparative analysis of cell proliferation on IB-decorated surfaces revealed similar properties of all tested IBs (Figure 7). Noteworthy, the ability of KPM335 IBs to penetrate into mammalian cells with fluorescent activity was fully conserved (Fig. 8), thus confirming a similar molecular architecture, mechanical stability and cell penetrability of IBs from the endotoxin-free strain. In fact, penetrability of these IBs was slightly but significantly higher than that of conventional, wild-type IBs $(p<0.05$ when measuring fluorescence and $p<0.01$ when determining the percentage of uptaking cells). Taken together, IBs lacking endotoxic activity hold promise for their use in biomedical applications (Garcia-Fruitos et al. 2012). 


\section{Discussion.}

$E$. coli is the most common cell factory for the production of recombinant proteins (Ferrer-Miralles and Villaverde 2013), including biopharmaceuticals for use in humans (Ferrer-Miralles et al. 2009). Like in other Gram-negative bacteria, the outer membrane of $E$. coli contains LPS as a main constituent that is released upon cell disruption to obtain intracellular products of biotechnological interest. In the human body, the LPS, also known as endotoxin, is a potent activator of inflammatory responses as it promotes the release of several of pro-inflammatory cytokines, which may cause high fever, severe tissue damage and death (Erridge et al. 2002). Therefore, many procedures for removal of LPS from recombinant protein preparations have been developed and adapted to specific processes to obtain products with different levels of purity (Magalhaes et al. 2007; Liu et al. 1997; Petsch and Anspach 2000). However, elimination of LPS requires considerable efforts and adds significant cost to downstream purification steps of proteins.

Lately, E. coli and other cell factories are being used to produce protein products of potential use in medicine, that are more complex than soluble proteins, including phage components, virus like particles and diverse nanostructured protein materials such as fibers, regular nanoparticles and IBs (Rodriguez-Carmona and Villaverde 2010; Vazquez and Villaverde 2013; Neus Ferrer-Miralles et al. 2013). Being in general considered as waste materials in protein production processes, bacterial IBs have gained interest as they are formed by significant fractions of properly folded, functional polypeptides (Garcia-Fruitos et al. 2005; Garcia-Fruitos et al. 2012; GonzalezMontalban et al. 2007). Due to their mechanical stability, the ability to penetrate mammalian cells in the absence of cellular damage and the release of functional protein, in a way similar to the release of functional hormones from amyloid repositories (Villaverde 2012), bacterial IBs became unexpectedly promising materials in drug delivery and in regenerative medicine (Garcia-Fruitos and Villaverde 2010; Liovic et al. 2012; Talafova et al. 2013; García-Fruitós et al. 2009; Seras-Franzoso et al. 2012; Seras-Franzoso J et al. 2013; Seras-Franzoso et al. 2013c; Seras-Franzoso et al. 2013b; Seras-Franzoso et al. 2013a; Tatkiewicz et al. 2013; Vazquez et al. 2012; Villaverde et al. 2012; Villaverde 2012). Although not determined quantitatively, contamination of IBs with bacterial LPS is a result of cell debris formation during cell disruption and separation (Neubauer et al. 2006; Georgiou and Valax 1999). Being highly porous and structurally more complex than soluble protein, LPS removal from IBs would necessarily pose technical problems. Here we have explored, as an alternative to commonly used LPS removal methods, the biofabrication of functional 
IBs in a newly developed endotoxin-free $E$. coli strain. We were particularly interested in whether these IBs produced in an endotoxin-free $E$. coli strain would maintain their mechanical and biological properties as the bacterial LPS could be a structural component of IBs supporting their key properties as functional biomaterials.

Here we show that, although the endotoxin-free strain KPM335 grew slower than the control strains (Fig. 1), the yield of the model protein produced in KPM335 was even slightly higher compared with the wild-type controls (Fig. 2). Remarkably, the specific fluorescence of VP1GFP deposited as IBs in KPM335 was significantly higher than in the wild-type strains (Fig. 3). This could be due to the lack of normal LPS as a contaminant in the material, which may result in a better protein folding with reduced quenching of fluorescence. Also, IBs from KPM335 adopted the pseudo-spherical geometry common in the material (Garcia-Fruitos et al. 2010), being morphologically indistinguishable from standard particles (Figs. 4 and 5). In the same context, endotoxin-depleted IBs used as topographies for mammalian cell proliferation (SerasFranzoso et al. 2013c) stimulated, as conventional IBs, cell spread (Fig. 7). This fact indirectly indicates that the LPS-free material has the same surface chemical properties and mechanical stability as wild-type protein particles and that LPS is not a structural element significantly contributing to the mechanical stability of the bacterial amyloids. Interestingly, the capability of LPS-free IBs to penetrate mammalian cells is slightly but significantly higher than that of the control material (Fig. 8B). Irrespective of the precise mechanism, this fact, together with their higher specific fluorescence (Fig. 3B), points out LPS-free IBs as valuable biocompatible materials for the delivery of protein drugs. On the other hand, among all bacterial cell factories (Ferrer-Miralles and Villaverde 2013) and non-bacterial protein production hosts developed thus far (Corchero et al. 2013), endotoxin-free E. coli strains seem to be an appealing alternative to minimize the biological risk of contaminations in the final products. This is especially relevant in the context of new systems biotechnology tools for this species (Lee et al. 2012) that further develops to become a true industrial factory, and makes biological fabrication of soluble proteins and nanostructured materials highly competitive with synthetic chemistry (Chen 2012; Vazquez and Villaverde 2013).

In the context of potential applications of IBs in drug delivery either in vitro for regenerative medicine (Seras-Franzoso $\mathrm{J}$ et al. 2013), in vivo in oral administration (Vazquez et al. 2012) or envisaging transdermal or cell-targeted delivery (Talafova et al. 2013; Liovic et al. 2012), endotoxin-free IBs hold promise for the development towards a powerful tool that ensures both functionality and additional biosafety, being particularly attractive regarding cost-effective production and regulatory issues. 


\section{Acknowledgments}

We are indebted to the Protein Production Platform (CIBER-BBN - UAB) for helpful technical assistance and for protein production and purification services (http://www.ciber-bbn.es/en/programas/89-plataforma-de-produccion-de-proteinasppp). The authors acknowledge the financial support granted to E.G.F. from INIA, (MINECO, RTA2012-00028-C02-02) Spain, and to A.V. from Agència de Gestió d'Ajuts Universitaris i de Recerca (2009SGR-108) and from the Centro de Investigación Biomédica en Red (CIBER) de Bioingeniería, Biomateriales y Nanomedicina financed by the Instituto de Salud Carlos III with assistance from the European Regional Development Fund. F.R. was supported by a predoctoral fellowship (Beca de Formación Doctoral "Francisco José de Caldas", Convocatoria 512-2010 de Colciencias and O.C-G received a PhD fellowship from MECD. A.V. has been distinguished with an ICREA ACADEMIA Award.

\section{Figure legends}

Figure 1. Optical densities at $550 \mathrm{~nm}\left(\mathrm{OD}_{550}\right)$ of the cell suspensions of $E$. coli strains MC4100/pTr99a-VP1GFP, BW30270/pTr99a-VP1GFP and KPM335/pTr99a-VP1GFP 3h post-induction of VP1GFP gene expression at different temperatures $\left(37^{\circ} \mathrm{C}, 25^{\circ} \mathrm{C}\right.$ and $\left.16^{\circ} \mathrm{C}\right)$.

Figure 2. Amount of soluble and insoluble VP1GFP produced in E. coli strains MC4100/pTr99a-VP1GFP, BW30270/pTr99a-VP1GFP and KPM335/pTr99a-VP1GFP $3 \mathrm{~h}$ post-induction of VP1GFP gene expression at different temperatures.

Figure 3. Green fluorescence of soluble and insoluble fractions in VP1GFP-producing E. coli strains MC4100, BW30270 and KPM335 (A) and specific fluorescence of soluble and insoluble VP1GFP produced in MC4100, BW30270 and KPM335 (B) at different temperatures.

Figure 4. Light microscopy images of VP1GFP-producing E. coli strains MC4100 (A), BW30270 (B), and KPM335 (C) 3h post-induction. Left to right: phase contrast microscopy at $100 \mathrm{X}$ magnification; fluorescence microscopy at $100 \mathrm{X}$ magnification; merged images using Image $\mathrm{J}$ software. 
Figure 5. Scanning electron micrographs of VP1GFP IBs isolated from E. coli strains MC4100 (left), BW30270 (middle) and KPM335 (right).

Figure 6. Stimulation of the hTLR4 signaling pathway by IBs produced in E. coli strains MC4100, BW30270 and KPM335. Relative NF-KB induction was measured following stimulation of HEK-Blue hTLR4 cells with tenfold serial dilutions of IBs.

Figure 7. Proliferation of 1BR3.G cells on matrices formed by IBs from E. coli strains MC4100, BW30270 and KPM335 at 37ㅇ C monitored at several times after seeding.

Figure 8. Internalization of IBs by HeLa cells. The HeLa cells were incubated with $5 \mu \mathrm{g}$ of VP1GFP IBs from E. coli strains BW30270 and KPM335. Internalization of IBs was monitored by measuring the intensity of fluorescence inside the cells $(A)$ and the fraction of fluorescent cells (B). 


\section{Reference List}

Badtke MP, Hammer ND and Chapman MR. (2009). Sci Signal, 2, e43.

Cano-Garrido O, Rodriguez-Carmona E, ez-Gil C, Vazquez E, Elizondo E, Cubarsi R, Seras-Franzoso J, Corchero JL, Rinas U, Ratera I, Ventosa N, Veciana J, Villaverde A and Garcia-Fruitos E. (2013). Acta Biomater, 9, 6134-6142.

Chen GQ. (2012). Microb Cell Fact, 11, 111.

Corchero JL, Gasser B, Resina D, Smith W, Parrilli E, Vazquez F, Abasolo I, Giuliani $M$, Jantti J, Ferrer $P$, Saloheimo M, Mattanovich D, Schwartz S Jr, Tutino $L$ and Villaverde A. (2013). Biotechnol Adv, 31, 140-153.

Diez-Gil C, Krabbenborg S, Garcia-Fruitos E, Vazquez E, Rodriguez-Carmona E, Ratera I, Ventosa N, Seras-Franzoso J, Cano-Garrido O, Ferrer-Miralles N, Villaverde A and Veciana J. (2010). Biomaterials, 31, 5805-5812.

Erridge C, Bennett-Guerrero E and Poxton IR. (2002). Microbes Infect, 4, 837-851.

Ferrer-Miralles N, Domingo-Espin J, Corchero JL, Vazquez E and Villaverde A. (2009). Microb Cell Fact, 8, 17.

Ferrer-Miralles N and Villaverde A. (2013). Microb Cell Fact, 12, 113.

Garcia-Fruitos E, Gonzalez-Montalban N, Morell M, Vera A, Ferraz RM, Aris A, Ventura S and Villaverde A. (2005). Microb Cell Fact, 4, 27.

Garcia-Fruitos E, Martinez-Alonso M, Gonzalez-Montalban N, Valli M, Mattanovich D and Villaverde A. (2007). J Mol Biol, 374, 195-205.

Garcia-Fruitos E, Seras-Franzoso J, Vazquez E and Villaverde A. (2010). Nanotechnology, 21, 205101.

Garcia-Fruitos E, Vazquez E, Diez-Gil C, Corchero JL, Seras-Franzoso J, Ratera I, Veciana J and Villaverde A. (2011). Trends Biotechnol, doi:10.1016/j.tibtech.2011.09.003.

Garcia-Fruitos E, Vazquez E, ez-Gil C, Corchero JL, Seras-Franzoso J, Ratera I, Veciana J and Villaverde A. (2012). Trends Biotechnol, 30, 65-70.

Garcia-Fruitos E and Villaverde A. (2010). Korean J Chem Eng, 27, 385-389.

García-Fruitós E, Rodríguez-Carmona E, Díez-Gil C, Ferraz RM, Vázquez E, Corchero JL, Cano-Sarabia M, Ratera I, Ventosa N, Veciana J and Villaverde A. (2009). Advanced Materials, 21, 4249-4253.

Georgiou G and Valax P. (1999). Methods Enzymol, 309, 48-58.

Gonzalez-Montalban N, Garcia-Fruitos E and Villaverde A. (2007). Nat Biotechnol, 25, 718-720.

J.Sambrook, EF.Fritsch and T.Maniatis. (1989). Molecular Cloning, a laboratory manual. New York. 
Laemmli UK. (1970). Nature, 227, 680-\&.

Lee SY, Mattanovich D and Villaverde A. (2012). Microb Cell Fact, 11, 156.

Liovic M, Ozir M, Bedina ZA, Peternel S, Komel R and Zupancic T. (2012). Microb Cell Fact, 11, 67.

Liu S, Tobias R, McClure S, Styba G, Shi Q and Jackowski G. (1997). Clin Biochem, 30, 455-463.

Magalhaes PO, Lopes AM, Mazzola PG, Rangel-Yagui C, Penna TC and Pessoa A, Jr. (2007). J Pharm Pharm Sci, 10, 388-404.

Maji SK, Perrin MH, Sawaya MR, Jessberger S, Vadodaria K, Rissman RA, Singru PS, Nilsson KP, Simon R, Schubert D, Eisenberg D, Rivier J, Sawchenko P, Vale W and Riek R. (2009). Science, 325, 328-332.

Mankar S, Anoop A, Sen S and Maji SK. (2011). Nano Rev, 2.

Neubauer P, Fahnert B, Lilie h and Villaverde A. (2006). pp. 237-292.

Neus Ferrer-Miralles, Escarlata Rodriguez-Carmona, Jose Luis Corchero, Elena Garcia-Fruitos, Esther Vazquez and Antonio Villaverde. (2013). Crit Rev Biotechnol, in press.

Petsch D and Anspach FB. (2000). J Biotechnol, 76, 97-119.

Rodriguez-Carmona E, Cano-Garrido O, Seras-Franzoso J, Villaverde A and GarciaFruitos E. (2010). Microb Cell Fact, 9, 71.

Rodriguez-Carmona E and Villaverde A. (2010). Trends Microbiol, 18, 423-430.

Seras-Franzoso J, Peebo K, Corchero JL, Tsimbouri, P. M., Unzueta U, Rinas, U., Dalby, M., Vazquez E, García-Fruitós, Elena, and Villaverde A. A nanostructured bacterial bio-scaffold for the sustained bottom-up delivery of protein drugs. Nanomedicine (Lond) . 2013.

Ref Type: In Press

Seras-Franzoso J, Diez-Gil C, Vazquez E, Garcia-Fruitos E, Cubarsi R, Ratera I, Veciana J and Villaverde A. (2011). Nanomedicine (Lond), doi: 10.2217/NNM.11.83.

Seras-Franzoso J, ez-Gil C, Vazquez E, Garcia-Fruitos E, Cubarsi R, Ratera I, Veciana $\mathrm{J}$ and Villaverde A. (2012). Nanomedicine (Lond), 7, 79-93.

Seras-Franzoso J, Peebo K, Garcia-Fruitos E, Vazquez E, Rinas U and Villaverde A. (2013a). Acta Biomater.

Seras-Franzoso J, Steurer C, Roldan M, Vendrell M, Vidaurre-Agut C, Tarruella A, Saldana L, Vilaboa N, Parera M, Elizondo E, Ratera I, Ventosa N, Veciana J, CampilloFernandez AJ, Garcia-Fruitos E, Vazquez E and Villaverde A. (2013b). J Control Release, 171, 63-72.

Seras-Franzoso J, Tsimbouri PM, Burgess KV, Unzueta U, Garcia-Fruitos E, Vazquez E, Villaverde A and Dalby MJ. (2013c). Nanomedicine (Lond).

Talafova K, Hrabarova E, Chorvat DA and Nahalka J. (2013). Microb Cell Fact, 12, 16. 
Tatkiewicz WI, Seras-Franzoso J, Garcia-Fruitos E, Vazquez E, Ventosa N, Peebo K, Ratera I, Villaverde A and Veciana J. (2013). ACS Nano.

Vazquez E, Corchero JL, Burgueno JF, Seras-Franzoso J, Kosoy A, Bosser R, Mendoza R, Martinez-Lainez JM, Rinas U, Fernandez E, Ruiz-Avila L, Garcia-Fruitos E and Villaverde A. (2012). Adv Mater, 24, 1742-1747.

Vazquez E, Roldan M, Diez-Gil C, Unzueta U, Domingo-Espin J, Cedano J, Conchillo O, Ratera I, Veciana J, Daura X, Ferrer-Miralles N and Villaverde A. (2010). Nanomedicine (Lond), 5, 259-268.

Vazquez E and Villaverde A. (2013). Nanomedicine (Lond), 8, 1895-1898.

Villaverde A. (2012). Nanomedicine (Lond), 7, 1277-1279.

Villaverde A and Carrio MM. (2003). Biotechnol Lett, 25, 1385-1395.

Villaverde A, Garcia-Fruitos E, Rinas U, Seras-Franzoso J, Kosoy A, Corchero JL and Vazquez E. (2012). Microb Cell Fact, 11, 76. 